\title{
PENGARUH NILAI UJIAN SEKOLAH BERSTANDAR NASIONAL TERHADAP PRESTASI BELAJAR PENDIDIKAN KEWARGANEGARAAN DI SEKOLAH MENENGAH PERTAMA
}

\author{
Nuryati $^{1}$ dan Nuni Astriana ${ }^{2}$ \\ 1,2 Pendidikan Pancasila dan Kewarganegaraan, Universitas Cokroaminoto Yogyakarta \\ Jl. Perintis Kemerdekaan, Gambiran, Umbulharjo, Kota Yogyakarta 55161 \\ ${ }^{1}$ Email: nuryatikip@ucy.ac.id \\ ${ }^{2}$ Email: nuniastriana97@gmail.com
}

\begin{abstract}
ABSTRAK
Penilaian pendidikan adalah proses pengumpulan dan pengolahan informasi untuk menentukan pencapaian hasil belajar peserta didik pada jenjang pendidikan dasar dan menengah. Penilaian dilakukan pada ranah spiritual, sosial, pengetahuan dan ranah keterampilan yang dilakukan secara terencana dan sistematis selama dan setelah proses pembelajaran suatu kompetensi muatan pembelajaran untuk kurun waktu tertentu.

Obek penelitian ini adalah nilai Ujian Sekolah Berstandar Nasional (USBN) dan prestasi belajar siswa SMP Bina Jaya Bantul dengan jumlah sampel sebanyak 14 siswa dalam waktu penelitian antara bulan April sampai Mei 2018. Penelitian ini dilakukan dengan tujuan untuk mengetahui besarnya pengaruh nilai USBN terhadap prestasi belajar. Adapun teknik pengumpulan data menggunakan tes dan dokumentasi.

Analisis data dengan metode validitas, reliabilitas, daya pembeda soal dan tingkat kesukaran soal dilakukan untuk menguji kualitas soal. Dokumentasi dilakukan untuk mendapatkan data nilai USBN. Dengan analisis statistik deskriptif untuk mengetahui nilai USBN dan prestasi belajar siswa. Untuk mengetahui besarnya pengaruh nilai USBN terhadap prestasi belajar siswa pada mata pelajaran Pendidikan Kewarganegaraan dilakukan dengan uji regresi sederhana, karena hanya ada satu variabel independen dan satu variabel dependen. Hasil pengujian regresi sederhana adalah koefisien regresi 0,942 dan $\mathrm{R}^{2}=0,698$ dengan arti bahwa nilai USBN berpengaruh terhadap prestasi belajar sebanyak 69,8\% sedangakan 30,2\% dipengaruhi faktor dari luar penelitian ini.
\end{abstract}

Kata Kunci: Nilai USBN, prestasi dan belajar.

\begin{abstract}
Educational assessment is the process of gathering and processing information to determine the achievement of student learning outcomes at the level of primary and secondary education. Assessment is carried out in the spiritual, social, knowledge and skills domains that are carried out in a planned and systematic manner during and after the learning process of a competency of learning content for a certain period of time.

The subject of this research is the value of the National Standard School Examination $(U S B N)$ and the learning achievement of Bina Jaya Bantul Middle School students with a sample size of 14 students during the study period from April to May 2018. This study was conducted with the aim to find out the magnitude of the effect of USBN scores on learning achievement. The data collection techniques use tests and documentation.

Data analysis using validity, reliability, distinguishing problems and the level of difficulty of the questions was done to test the quality of the questions. Documentation is done to get the USBN value data. With descriptive statistical analysis to find out the value of USBN and student achievement. To find out the magnitude of the effect of USBN scores on student achievement in Civics Education subjects is done with a simple regression test, because there is only one
\end{abstract}


independent variable and one dependent variable. Simple regression test results are the regression coefficient 0.942 and $R 2=0.698$ with the meaning that the value of the USBN affects learning achievement as much as $69.8 \%$ while $30.2 \%$ is influenced by factors from outside this study.

Keywords: USBN score, achievement and learning.

\section{LATAR BELAKANG}

Pendidikan merupakan aspek yang sangat mendasar bagi pembangunan bangsa suatu negara, dalam penyelengaraan pendidikan di sekolah yang melibatkan guru sebagai pendidik dan siswa sebagai peserta didik yang diwujudkan dengan interaksi belajar mengajar atau proses pembelajaran. Dalam konteks penyelenggaraan pembelajaran, guru sebagai pendidik dengan sadar merencanakan pengajarannya secara sistematis dan berpedoman pada seperangkat aturan dan tujuan pendidikan. Pendidikan akan terlaksana sesuai tujuan apabila faktor pendukung atau saran dan prasarana memadai untuk seluruh wilayah Indonesia.

Sebagaimana dalam Undang-Undang Nomor 20 Tahun 2003 tentang Sistem Pendidikan Nasional bahwa Pendidikan adalah usaha sadar dan terencana untuk mewujudkan, mengembangkan potensi dirinya untuk memiliki kekuatan spiritual keagamaan, pengendalian diri, kepribadian, kecerdasan, akhlak mulia serta keterampilan yang diperlukan dirinya, masyarakat, bangsa dan Negara. Pendidikan nasional adalah pendidikan yang berdasarkan Pancasila dan Undang-Undang Dasar Negara Republik Indonesia Tahun 1945 yang berakar pada pada nilai-nilai agama, kebudayaan nasional Indonesia dan tanggap terhadap tuntutan perubahan zaman.(2006:3).

Sebagaimana dalam buku Pelatihan dan Pendampingan Implementasi Kurikulum 2013 Sekolah Menengah Kejuruan Kementerian pendidikan dan kebudayaan, penilaian merupakan proses pengumpulan dan pengolahan informasi untuk mengukur pencapaian hasil belajar peserta didik dalam ranah (spiritual dan sosial), ranah pengetahuan dan ranah keterampilan yang dilakukan secara terencana dan sistematis selama dan setelah proses pembelajaran suatu kompetensi muatan pembelajaran untuk kurun waktu tertentu (2018:1).

Standar penilaian pendidikan adalah standar nasional pendidikan yang berkaitan dengan mekanisme, prosedur dan instrumen penilaian hasil belajar peserta didik. Penilaian pendidikan adalah proses pengumpulan dan pengolahan informasi untuk menentukan pencapaian hasil belajar peserta didik. Penilaian hasil belajar peserta didik pada jenjang pendidikan dasar dan menengah pada prinsip-prinsip yang ada. (Iskandar, 2012:40). Penilaian hasil belajar berperan membantu peserta didik mengetahui capaian pembelajaran, memperoleh informasi tentang kelemahan dan kekuatan proses 
pembelajaran dan hasil belajar. Dalam pendidikan berbasis standar, kurikulum berbasis kompetensi dan pendekatan belajar tuntas penilaian proses dan hasil belajar merupakan parameter tingkat pencapaian kompetensi minimal yang menjadi batas ketuntasan belajar.

Kurikulum 2013 digunakan beberapa teknik penilaian salah satunya penilaian pengetahuan dapat dilakukan melalui tes tetulis, tes lisan dan penugasan. Berdasarkan waktu pelaksanaannya, penilaian pengetahuan terbagi menjadi tiga bagian yaitu Penilaian Harian (PH), Penilaian Akhir Semester (PAS) dan Penilaian Akhir Tahun (PAT). Penilaian yang dilaksanakan oleh pemerintah, akan dilaksanakan pada semester genap ynag dinamakan Ujian Sekolah Berstandar Nasional (UBSN).

Berbicara masalah pendidikan, berbicara masalah kecerdasan intelektual atau kecerdasan pengetahuan. Kecerdasan pengetahuan erat hubungannya dengan nilai. Semenjak sekolah PAUD sampai PT kita selalu akrab dengan namanya nilai. Nilai adalah balasan yang diberikan setimpal dengan apa yang kita kerjakan. Didalam masyarakat, nilai yang kita dapatkan pasti akan berimbas juga terhadap pengakuan orang lain. Jika kita sering mendapat nilai bagus apalagi mendapat rangking di kelas sudah barang tentu masyarakat akan berbicara. Realita sekarang, melihat fenomena yang terjadi sekarang ini kecerdasan seseorang yang tertulis diatas lembaran kertas dijadikan tolok ukur atau acuan kecerdasan seseorang, khususnya dari segi kecerdasan intelektual.

Seseorang yang mendapat nilai baik mereka akan merasa bangga, tidak dipungkiri dimanapun anak-anak ingin mendapatkan nilai bagus disetiap mata pelajaran. Mata pelajaran yang diujikan pada setiap sekolah baik yang diujikan secara nasional maupun sekolah. Kecerdasan intelektual harus diimbangi dengan kecerdasan emosional atau afektif. Nilai kecerdasan sosial atau emosional dan kecerdasan intelektual khususnya mata pelajaran Pendidikan Kewarganegaraan sangat erat hubungannya dengan nilai karakter. Nilai yang diperlukan bangsa Indonesia untuk mendasari anak bangsa. Dalam kurikulum 2013 ditekankan dengan istilah PPK (Penguatan Pendidikan Karakter) untuk semua jenjang pendidikan. Dengan harapan peserta didik dapat memiliki karakter yang baik terutama religious, jujur dan disiplin dalam mengerjakan soal-soal ujian.

Karaker disiplin dan jujur salah satu nilai karakter yang akan menjadi dasar peserta didik dalam penyelesaiaan soal-soal atau dalam mengerjakan soal khususnya soal Ujian Sekolah Berstandar Nasional (USBN). Adapun untuk penyusunan soal ujian sekolah berstandar nasional dilaksanakan oleh guru dari beberapa sekolah yang bergabung dalam MGMP. Tetapi Ujian Sekolah Berstandar Nasional (USBN) bukan satu-satunya assessment. 
Diantara bentuk penilaian salah satunya penilaian belajar siswa adalah Ujian Sekolah Berstandar Nasional (USBN) tetapi disamping Ujian Sekolah Berstandar Nasional masih ada penilaian yang lain antara lain penilaian harian. Penilaian harian dilakukan pada akhir beberapa Kompetensi Dasar. Hal ini dilakukan untuk mengetahui tingkat pemahaman peserta didik pada materi yang sudah disampaikan guru. Beberapa penilaian akan mengetahui seberapa tingkat pemahaman pesesrta didik pada materi. Ini tidak sekedar mencari jawaban yang pendek tetapi mengajarkan siswa untuk menerangkan, menjelaskan dan berargumentasi.

Peserta didik dengan nilai pengetahuan atau nilai ujian sekolah berstandar nasional baik belum tentu memiliki prestasi belajar baik. Prestasi belajar yang dapat diukur dalam bentuk angka adalah prestasi belajar dari ranah kognitif atau pengetahuan, peserta didik dapat memahami pengetahuan dengan cara mengamati dan mencoba (mendengar, melihat dan membaca) dan menanya berdasarkan rasa.

\section{KAJIAN TEORI}

1. Pengertian Nilai

Nilai adalah esensi yang melekat pada suatu yang sangat berarti bagi kehidupan manusia, khususnya mengenai kebaikan dan tindak kebaikan suatu hal. Nilai artinya sifat-sifat atau hal-hal yang penting atau berguna bagi kemanusiaan. Nilai adalah suatu yang bersifat abstrak, ideal, nilai bukan benda konkrit, bukan fakta, tidak hanya persoalan benar atau salah yang menuntut pembuktian empirik, melainkan penghayatan sosial yang dikehendaki, disenangi dan tidak disenangi.

Nilai adalah harga, makna, isi dan pesan, semangat, atau jiwa yang tersurat dan tersirat dalam fakta, konsep, dan teori, sehingga bermakna secara fungsional. Pengertian nilai adalah harga atau kualitas sesuatu. Kesimpulan dari beberapa pengertian nilai di atas, bahwa nilai adalah harga yang melekat yang bersifat abstrak sehingga memerlukan pembuktian dan bermakna.

2. Pendidikan Kewarganegaraan

Pengertian Pendidikan Kewarganegaraan berawal dari istilah Civic Education diterjemahkan kedalam bahasa Indonesia menjadi Pendidikan Kewarganegaraan dan akhirnya menjadi Pendidikan Kewarganegaraan. Istilah Pendidikan Kewarganegaraan diawali oleh Azzra dan Tim ICCE (Indonesia Center for ivic Education) dari Universitas Islam Jakarta, sebagai pengembang Civic Education pertama di perguruan 
tinggi. Penggunaan istilah Pendidikan Kewarganegaraan diawali oleh Winataputra dkk dari Tim CICED (Center Indonesia for Civic Education), Tim ICCE (2005:6).

Menurut Kerr, Pendidikan Kewarganegaraan dirumuskan secara luas yang mencakup proses penyiapan generasi muda untuk mengambil peran dan tanggungjawab sebagai warga Negara, dan secara khusus peran pendidikan termasuk didalamnya persekolahan, pengajaan dan belajar dalam proses penyiapan warga Negara tersebut (Winataputra dan Budimansyah, 2007:4).

Pendidikan Kewarganegaraan diartikan sebagai penyiapan generasi muda (siswa) untuk menjadi warga Negara yang memiliki pengetahuan, kecakapan dan nilai-nilai yang diperlukan untuk berpartisipasi dalam masyarakat (Samsuri, 2011:28). Pendidikan Kewarganegaraan adalah mata pelajaran yang memfokuskan pada pembentukan warga Negara yang memahami dan mampu melaksanakan hak-hak dan kewajiban untuk menjadi warga Negara Indonesia yang terampil, cerdas, berkarakter yang diamanatkan oleh Pancasila dan UUD 1945 (Depdiknas, 2006:49).

Pendapat lain tentang Pendidikan Kewarganegaraan. Pendidikan Kewarganegaraan merupakan usaha untuk membekali peserta didik dengan pengetahuan dan kemampuan dasar berkenaan dengan hubungan antar warga Negara dengan Negara serta pendidikan pendahuluan bela Negara agar dapat diandalkan oleh bangsa dan Negara (Soemantri, 2001:154).

Berdasarkan beberapa pengertian diatas dapat disimpulkan bahwa Pendidikan Kewarganegaraan adalah suatu mata pelajaran yang merupakan satu rangkaian proses untuk mengarahkan peserta didik menjadi warga Negara yang berkarakter bangsa Indonesia, cerdas, terampil dan bertanggungjawab sehingga dapat berperan aktif dalam masyarakat sesuai ketentuan Pancasila dan UUD NRI Tahun 1945.

3. Prestasi Belajar

Prestasi belajar merupakan serangkian dua kata, yaitu prestasi dan belajar. Dimana dua kata tersebut saling berkaitan dan mempunyai arti yang berbeda. Oleh karena itu, sebelum membahas lebih dalam tentang prestasi belajar, terlebih dahulu peneliti telusuri kata tersebut satu persatu. Adapun pengertian prestasi sebagai berikut:

a. Menurut Zainal Arifin (2012:37) bahwa prestasi adalah hasil dari kemampuan keterampilan dan sikap seseorang dalam menyelesaikan suatu hal.

b. Menurut Hamdani (2011:137) prestasi yaitu hasil dari suatu kegiatan yang telah dikerjakan, diciptkan baik secara individual maupun kelompok. 
c. Syaiful Bahri Djamarah (2012:21) prestasi yaitu hasil dari suatu kegiatan yang telah dikerjakan, diciptakan, yang menyenangkan hati yang diperoleh dengan jalan keuletan kerja, baik secara individual maupun kelompok dalam bidang kegiatan tertentu.

Dari beberapa pengertian prestasi di atas, dapat diambil kesimpulan bahwa prestasi adalah suatu hasil yang dicapai dari suatu kegiatan yang telah dikerjakan, baik secara individu maupun kelompok.

Pengertian belajar menurut para ahli sebagai berikut:

a. Morgan dalam Iskandar (2012:35) belajar adalah setiap perubahan yang relatif menetap dalam tingkah laku yang terjadi sebagai suatu hasil dari latihan atau pengalaman.

b. James P. Chaplin, dalam Iskandar (2012:35) Learning (hal, pengetahuan) yang berarti perolehan dari sembarang perubahan yang relative permanent dalam tingkah laku sebagai hasil praktek aktualisasi pengalaman.

c. Belajar adalah suatu kegiatan interaksi antar individu dengan lingkungannya yang bertujuan untuk mengadakan perubahan dalam diri seseorang mencakup perubahan tingkah laku, sikap, kebiasaan, ilmu pengetahuan, keterampilan, dan sebagainya yang bersifat konstan (Makmun Khairani, 2014: 5)

Kesimpulan dari beberapa pengertian belajar di atas, bahwa belajar adalah proses atau kegiatan antara individu dengan lingkungan sehingga terjadi perubahan perilaku yang sifanya menetap sebagai hasil dari pengalaman atau latihan.

Kesimpulan pengertian prestasi belajar adalah hasil yang dicapai dari suatu proses antara individu dengan lingkungan sehingga terjadi perubahan perilaku yang sifanya menetap sebagai hasil dari pengalaman atau latihan.

Dikatakan belajar apabila terjadi perubahan pada diri individu yang belajar. Perubahan tersebut dari segi kognitif, afektif, dan psikomotor. Dalam hubungan dengan usaha pendidikan, belajar adalah key term (istilah kunci) yang sangat vital dalam setiap usaha pendidikan, tanpa belajar sesungguhnya tak pernah ada pendidikan (Iskandar, 2012: 36).

Belajar merupakan suatu perubahan dalam tingkah laku, dimana perubahan itu dapat mengarah pada perubahan tingkah laku yang lebih baik tetapi ada juga kemungkinan mengarah pada tingkah laku yang buruk. Belajar juga merupakan suatu perubahan yang terjadi melalui latihan atau pengalaman dan perubahan itu relatif 
menetap dan tingkah laku yang mengalami perubahan belajar menyangkut kepribadian, baik fisik maupun psikis.

\section{KERANGKA PEMIKIRAN}

Penilaian merupakan proses pengumpulan dan pengolahan informasi untuk mengukur pencapaian hasil belajar peserta didik khususnya penilaian pengetahuan. Penilaian pengetahuan Pendidikan Kewarganeraan yang salah satunya Ujian Sekolah Berstandar Nasional (USBN) dilaksanakan setiap sekolah, adapun untuk bentuk soal terdiri dari soal pilihan ganda dan soal uraian. Soal USBN dari pusat $25 \%$ terdiri dari soal pilihan ganda 10 dan 1 uraian. Penyusun soal USBN adalah MGMP masing-masing mata pelajaran. Penilaian pengetahuan akan menentukan hasil belajar peserta didik dalam bentuk nilai. Nilai pengetahuan peserta didik khususnya nilai USBN dipengaruhi oleh jumlah soal, tingkat kesulitan soal, tingkat pemahaman soal dan durasi.

Peserta didik dengan nilai pengetahuan yang baik belum tentu memiliki prestasi yang baik dalam belajar. Prestasi belajar peserta didik yang bisa diukur dengan angka adalah penilaian dari ranah kognitif, peserta didik dapat memahami pengetahuan factual dan konseptual dengan cara mengamati dan mencoba (mendengar, melihat dan membaca) dan menanya berdasarkan rasa.

Dari uraian di atas dapat penulis gambarkan kerangka pemikiran sebagai berikut:

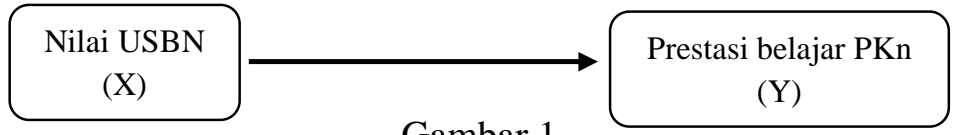

Gambar 1

Pengaruh nilai Ujian Sekolah Berstandar Nasional (USBN) terhadap prestasi belajar

\section{METODE PENELITIAN}

1. Jenis Penelitian

Jenis penelitian adalah deskriptif kuantitatif, karena gejala-gejala dari hasil penelitian yang berupa data dikonversikan terlebih dahulu kedalam bentuk angka-angka atau dengan teknik statistik.

2. Tempat penelitian

Tempat penelitian ini di Sekolah Menengah Pertama (SMP) Bina Jaya, Kecamatan Banguntapan, Kabupaten Bantul.

3. Waktu penelitian

Penelitian ini dilakukan mulai bulan April 2018 sampai dengan Mei 2018.

4. Populasi 
Populasi dalam penelitian ini adalah siswa kelas VII sebanyak 39 siswa, kelas VIII sebanyak 19 siswa dan siswa kelas IX sebanyak 14 siswa.

\section{Sampel}

Sampel dalam penelitian ini adalah siswa kelas IX sebanyak 14 siswa, karena yang melaksanakan Ujian Sekolah Berstandar Nasional (USBN) kelas IX.

6. Variabel Penelitian

a. Variabel bebas (X)

Variabel bebas (independen) dalam penelitian ini adalah nilai Ujian Sekolah Berstandar Nasional (USBN) kelas IX. Nilai USBN peneliti dijadikan sebagai variabel independen karena nilai USBN belum diakumulasikan dengan nilai yang lain.

b. Variabel terikat $(\mathrm{Y})$

Variabel terikat (dependen) dalam penelitian ini adalah prestasi belajar, yaitu hasil yang dicapai seseorang yang mengakibatkan adanya perubahan sikap, pola pikir dan perilaku sebagai hasil pengalaman.

Prestasi belajar merupakan hasil yang dicapai seseorang yang mengakibatkan adanya perubahan sikap, pola pikir dan perilaku sebagai hasil pengalaman. Adapun untuk pengukurannya akan dijabarkan menjadi sub variabel, indikator dan instrumen dalam bentuk pertanyaan.

7. Teknik pengumpulan data

Teknik pengumpulan data pada penelitian ini menggunakan tes dan dokumentasi.

a. Tes

Teknik pengumpulan data dalam penelitian ini menggunakan tes berupa soal. Langkah-langkah dalam penyusunan soal adalah penyusunan kisi-kisi soal, soal, kunci jawaban, penskoran, membuat tabel jawaban responden, menganalisis soal atau pertanyaan dan membuat laporan dalam bentuk skrip. Variabel dalam penelitian ini terdiri dari nilai USBN sebagai variabel independen atau bebas dan prestasi belajar sebagai variabel dependen atau terikat, seperti pada tabel 1 dibawah ini:

Tael 1 Variabel Penelitian

\begin{tabular}{|c|c|c|}
\hline No & Variabel & Nama \\
\hline 1 & Bebas & Nilai USBN \\
2 & Terikat & Prestasi Belajar \\
\hline \multicolumn{3}{|c|}{ Sumber: Data diolah } \\
\hline
\end{tabular}


b. Dokumentasi

Dokumentasi dalam penelitian ini berupa nilai USBN mata pelajaran Pendidikan Kewarganegaraan di Sekolah Menengah Pertama Bina Jaya Bantul Tahun Pelajaran 2018/ 2019. Kriteria prestasi belajar dalam hal ini Kriteria Ketuntasan Minimal (KKM) merupakan tolok ukur untuk mengukur nilai pengetahuan ditunjukkan pada tabel 3, di bawah ini:

Tabel 3 Kriteria ketuntasan minimal

\begin{tabular}{|c|c|}
\hline Skor & Predikat \\
\hline $88-100$ & $\mathrm{~A}$ \\
\hline $74-87$ & $\mathrm{~B}$ \\
\hline $60-73$ & $\mathrm{C}$ \\
\hline$<60$ & $\mathrm{D}$ \\
\hline
\end{tabular}

Sumber: Data diolah

\section{PEMBAHASAN}

Populasi dalam penelitian ini adalah siswa kelas VII sebanyak 39 siswa, kelas VIII sebanyak 19 siswa dan siswa kelas IX sebanyak 14 siswa. Sedangkan sampel dalam penelitian ini adalah siswa kelas IX sebanyak 14 siswa. Analisis deskripsi dilakukan berdasarkan berdasarkan jenis kelamin dan usia dan nilai prestasi belajar dengan Kriteria Ketuntasan Minimal (KKM) 60. Analisis yang dilakukan berdasarkan nilai prestasi belajar dapat disimpulkan bahwa mayoritas nilai prestasi belajar siswa antara 74-87 dengan predikat B. Sedangkan siswa yang mendapatkan nilai antara 88-100 dengan predikat A sebanyak 1 siswa.

Analisis yang dilakukan berdasarkan jenis kelamin, mayoritas peserta didik berjenis kelamin laki-laki sebanyak 9 peserta didik atau 64.3\% sedangkan yang berjenis kelamin sebanyak 5 peserta didik atau 35.7\%. Sedangkan analisis deskripsi berdasarkan usia diperoleh bahwa peserta didi yang berusia 16 tahun sebanyak 7 peserta didik atau $50 \%$, peserta didik yang berusia 15 dan 17 tahun masing-masing sebanyak 3 peserta didik atau $21.4 \%$ sedangkan peserta didik yang berusia 18 tahun sebanyak 1 peserta didi atau $7.2 \%$.

Berdasarkan hasil analisis data dapat disimpulkan bahwa prestasi belajar dipengaruhi oleh konsep diri sebesar 69,8\% sedangkan 30,2\% dipengaruhi faktor dari luar penelitian. Adapun hasil pengujian analisis regresi tunggal diperoleh persamaan regresi: $\mathrm{Y}=21,756+0,942 \mathrm{X}$. Berdasarkan persamaan regresi tunggal dapat diperoleh konstanta $(\alpha)$ 
sebesar 21,756 dengan pengertian jika nilai USBN (X) atau sama dengan nol (0) maka besarnya tingkat prestasi belajar (Y) sebesar 21,756 satuan, variabel nilai USBN (X) diperoleh nilai koefisien sebesar 0,942 yang berarti apabila nilai USBN (X) meningkat satu satuan, maka prestasi belajar (Y) akan meningkat sebesar 0,942 satuan.

Pengujian hipotesis dilakukan melalui pengujian signifikansi koefisien regresi variabel nilai USBN. Dengan hipotesis nilai USBN berpengaruh terhadap prestasi belajar siswa.

Hasil analisis regresi membuktikan besarnya koefisien regresi 0,942 dengan tingkat signifikansi $\alpha=5 \%$, maka koefisien regresi tersebut signifikan karena $\rho=0,000>0,05$.

\section{SIMPULAN DAN SARAN}

A. Simpulan

Berdasarkan hasil pengujian hipotesis dengan menggunakan regresi tunggal didapatkan hasil tingkat koefisien regresi sebesar 0,942, dengan tingkat signifikansi $\alpha=5 \%$. Maka koefisien tersebut signifikan karena $\rho=0,000<0,05$. Berdasarkan hasil tersebut, dapat disimpulkan bahwa nilai USBN berpengaruh terhadap prestasi belajar mata pelajaran Pendidikan Kewarganegaraan. Peserta didik yang memiliki nilai USBN baik kemungkinan besar memiliki prestasi baik di sekolah.

B. Saran

Berdasarkan uji statistik dan analisis tersebut dapat diberikan saran sebagai berikut:

1. Untuk meningkatkan nilai USBN dan prestasi belajar peserta didik harus ada kerjasama semua pihak, terutama guru sebagai ujung tombak pendidikan.

2. Sekolah tidak perlu menargetkan hasil nilai USBN maupun prestasi belajar peserta didik terlalu tinggi, karena harus memperhatikan kondisi sekolah terutama dari segi sarana dan prasana dan keadaan peserta didik terutama tingkat kecerdasan peserta didik.

3. Dalam penyusunan soal harus memperhatikan 2 hal yaitu tingkat berpikir peserta didik dan narasi yang berfngsi untuk sebagai stimulus atau rangsangan.

\section{DAFTAR PUSTAKA}

Arikunto, Suharsimi, (2013). Dasar-Dasar Evaluasi Pendidikan. Jakarta: Bumi Aksara.

Budimansyah, (2007), Civic Education: Konstek, Landasan, Bahan Ajar Dan Kultur Kelas, Bandung: Program Studi Pendidikan Kewarganegaraan, SPSUPI http://file.upi.edu/direktorat/fpbs/jur._pend._bahasa_arab/195204141980021dudung_rahmt _hidayat/hakikat_dan_makna nilai.pdf diakses tanggal 30 Maret 2019. 
https://www.zonareferensi.com/pengertian-nilai/ diakses tanggal 30 Maret 2019.

Iskandar, (2012), Psikologi Pendidikan (Sebuah Orientasi Baru), Jakarta: Referensi.

Kementerian Pendidikan dan Kebudayaan, (2018), Pelatihan DAN Implementasi Kurikulum 13 Sekolah Dasar, Jakarta.

Makmun, Khairani, (2014), Psikologi Belajar, Yogyakarta: Aswaja Pressindo.

Samsuri, (2011), Pendidikan Karakter Warga Negara, Yogyakarta: Diandra Pustaka Indonesia.

Soemantri, (2001), Pembaharuan Pendidikan IPS, Bandung: Rosada Karya.

Sudijono, Anas. (2011). Pengantar Evaluasi Pendidikan. Jakarta: PT Raja Grafindo Persada.

Sugiyono, (2002), Metode Penelitian Bisnis, Bandung: Alfabeta. (2012), Metode Penelitian Managemen, Bandung: Alfabeta.

Republik Indonesia, 2003. Undang-undang Republik Indonesia, Nomor 20, Tahun 2003, Tentang Sistem Pendidikan Nasional, Sekretariat Negara, Jakarta.

Republik Indonesia, 2018, Undang-undang Republik Indonesia Tahun 1945, Sekretariat Jenderal MPR RI, Jakarta. 